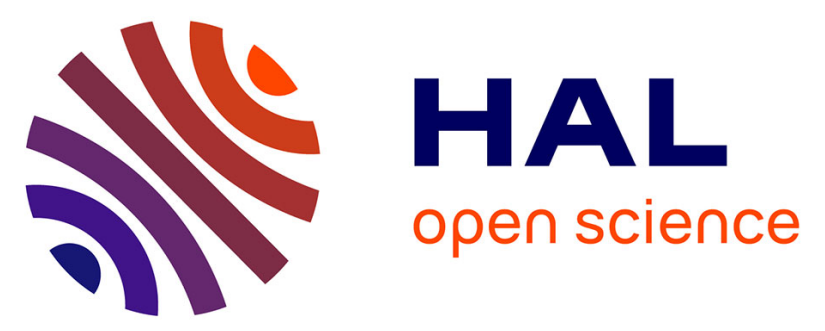

\title{
A high-resolution stable isotopic record from the Junggar Basin (NW China): Implications for the paleotopographic evolution of the Tianshan Mountains
}

Julien Charreau, Malinda Louise Kent-Corson, Laurie Barrrier, Romain Augier, Bradley D. Ritts, Yan Chen, Christian France-Lannord, Caroline Guilmette

\section{To cite this version:}

Julien Charreau, Malinda Louise Kent-Corson, Laurie Barrrier, Romain Augier, Bradley D. Ritts, et al.. A high-resolution stable isotopic record from the Junggar Basin (NW China): Implications for the paleotopographic evolution of the Tianshan Mountains. Earth and Planetary Science Letters, 2012, 341-344, pp.158-169. 10.1016/j.epsl.2012.05.033 . insu-00715969

\section{HAL Id: insu-00715969}

https://hal-insu.archives-ouvertes.fr/insu-00715969

Submitted on 10 Jul 2012

HAL is a multi-disciplinary open access archive for the deposit and dissemination of scientific research documents, whether they are published or not. The documents may come from teaching and research institutions in France or abroad, or from public or private research centers.
L'archive ouverte pluridisciplinaire HAL, est destinée au dépôt et à la diffusion de documents scientifiques de niveau recherche, publiés ou non, émanant des établissements d'enseignement et de recherche français ou étrangers, des laboratoires publics ou privés. 


\title{
A high-resolution stable isotopic record from the Junggar Basin (NW China): implications for the paleotopographic evolution of the Tianshan Mountains
}

\author{
Julien Charreau ${ }^{1}$, Malinda Louise Kent-Corson ${ }^{2}$, Laurie Barrier ${ }^{3}$, Romain Augier ${ }^{4}$, Bradley D. Ritts ${ }^{5}$, Yan Chen ${ }^{4}$, \\ Christian France-Lannord ${ }^{1}$ and Caroline Guilmette ${ }^{1,6}$ \\ 1. Université de Lorraine, Centre de Recherche Pétrographique et Géochimique, 15 rue Notre Dame des \\ Pauvres, 54501 Vandoeuvre lès Nancy, France, phone : (33)383594227 Fax: (33)383511798, \\ charreau@crpg.cnrs-nancy.fr, cfl@crpg.cnrs-nancy.fr, guilmet@crpg.cnrs-nancy.fr \\ 2. Nanyang Technological University; Division of Earth Sciences; 50 Nanyang Ave., Singapore 269269; \\ Phone : (65) 65927542 Fax: (65) 67901585; mkentcorson@ ntu.edu.sg \\ 3. Institut de Physique du Globe de Paris, 4 place Jussieu, 75252 Paris Cedex 05 FRANCE; Phone: 33- \\ 1.44.27.49.34, Fax: 33-1-44277463; barrier@ipgp.jussieu.fr \\ 4. Institut des Sciences de la Terre d'Orléans; 1A, rue de la Férollerie, 45071 Orléans Cedex 2, Orléans Cedex \\ 2, France; Yan.Chen@univ-orleans.fr, Romain.augier@univ-orleans.fr \\ 5. Chevron Asia Pacific Exploration and Production, 30 Raffles Place 08-00, Singapore 048622; Phone; (65) \\ 63181917, BradleyRitts@chevron.com \\ 6. Now at: Centre d'étude Nordique-Takuvik, University of Laval, 1045, Avenue de la Médecine Québec, \\ Canada, caroline.guilmette@takuvik.ulaval.ca \\ * Corresponding author: charreau@crpg.cnrs-nancy.fr
}

\begin{abstract}
This study presents high-resolution oxygen and carbon isotopic records of paleosol carbonates from fluvial sediments and lacustrine carbonates, sampled from the Jingou He and Kuitun He stratigraphic sections, located in the northern Tianshan piedmont. These sections expose remarkable outcrops of Junggar foreland basin sediments that have been previously dated by high-resolution magnetostratigraphy to between $\sim 23.6$ and $\sim 1 \mathrm{Ma}$, and $\sim 10.5$ and $\sim 3.1 \mathrm{Ma}$, respectively. A total of 216 samples of fluvio-lacustrine sediments were collected from which isotopic analyses yield $\delta^{18} \mathrm{O}$ (SMOW) values that range from 13.7 to $29.9 \%$ in the Jingou $\mathrm{He}$ section, and 16.3 to $21.0 \%$ in the Kuitun He section. $\delta^{13} \mathrm{C}(\mathrm{PDB})$ values range from -12.9 to $3.0 \%$ in the Jingou He section and -7.8 to $-4.0 \%$, in the Kuitun He section. $\delta^{18} \mathrm{O}$ values decrease between $\sim 25$ and $23 \mathrm{Ma}$, and then remain relatively steady, with the exception of one period that contains samples with higher oxygen isotope values at $\sim 16 \mathrm{Ma}$. During the periods when there are samples that overlap in time from the Kuitun $\mathrm{He}$ and Jingou $\mathrm{He}$ sections, we observe a difference of $\sim 1.7 \%$ between values from the two locales. The $\delta^{13} \mathrm{C}$ values also decrease
\end{abstract}


between $\sim 25$ and $23 \mathrm{Ma}$, and then remain relatively steady until $\sim 10 \mathrm{Ma}$ with, again, one short period of higher values $\sim 16 \mathrm{Ma}$. Then, between $\sim 10$ and $3.1 \mathrm{Ma}$, carbon isotope values progressively increase. We interpret that $\delta^{18} \mathrm{O}$ and $\delta^{13} \mathrm{C}$ isotopic values during lacustrine periods ( $\sim 25-23 \mathrm{Ma}$ and $\sim 16 \mathrm{Ma}$ ) as largely controlled by evaporation and opening/closing of the lake to external inputs. We interpret the $\delta^{18} \mathrm{O}$ values of paleosol carbonate in the Junggar Basin to be influenced by the hypsometry of the high Tianshan range while the $\delta^{13} \mathrm{C}$ values may record the uplift history of the depositional area in the foreland basin itself as well as the isotopic composition of plants. Consequently, we conclude that the Jingou He and Kuitun He drainage basins in the Central Tianshan have remained at relatively unchanged elevations for the past $\sim 20$ Ma. We also suggest that the elevation of the southern part of the foreland basin increased between $\sim 10$ to $\sim 3.1 \mathrm{Ma}$, probably as a result of tectonic deformation in the piedmont and sedimentary filling of the sedimentary basin. The carbon isotope record remains relatively stable through time, and isotopic values suggest that there was little or no expansion of $\mathrm{C} 4$ plants in this region in the late Miocene.

\section{Introduction}

Mountains are the complex expression of the interactions between tectonic deformation, climate, and surface processes such as sedimentation and erosion (e.g Avouac and Burov, 1996; Beaumont et al., 1988; Burbank, 1992; Cobbold et al., 1993; Koons, 1987; Molnar and England, 1990; Whipple and Meade, 2006), both of which drive mass transfer from the uplifting zone toward the flanking basins (e.g. Charreau et al., 2009b; Métivier et al., 1999; Zhang et al., 2001). To better decipher the relative impact of these processes, long term and quantitative estimates of paleotopographic variations are needed. This is particularly true in Asia, where the India

collision that began $~ 55$ Ma ago (Leech et al., 2005; Patriat and Achache, 1984) has generated the growth of ranges with some of the greatest relief on Earth. The Tianshan Mountains lie 1700 $\mathrm{km}$ north of the India-Asia suture zone and dominate the topography of Central Asia over an EW distance of over $2500 \mathrm{~km}$ with summits higher than $7000 \mathrm{~m}$. Present-day shortening rates exceed $20 \mathrm{~mm} / \mathrm{yr}$ across the range (Abdrakhmatov et al., 1996; Reigber et al., 2001), and attest to the great magnitude of intracontinental deformation. While the geological structure of the range has resulted from a complex Paleozoic history of accretionary and intracontinental deformation 
(e.g. Gao et al., 1998; Hendrix et al., 1992; Wang et al., 2008a; Windley et al., 1990), the present topography appears to be related to the tectonic reactivation of these structures induced by the India-Asia collision (e.g. Dumitru et al., 2001; Sobel and Dumitru, 1997; Tapponnier and Molnar, 1979). This uplift has widely affected Central Asian climate and environment during Cenozoic times (Fluteau et al., 1999; Raymo and Ruddiman, 1992; Ruddiman and Kutzbach, 1989). Indeed, the amount of rainfall in the northern Tianshan piedmont today is one order of magnitude greater than in the southern Tianshan (Figure 1), indicating that the Tianshan act as a significant topographic barrier to atmospheric circulation from the north, including the Central Asian and Arctic air masses (Araguas-Araguas et al., 1998). Thus, understanding how and when this relief was built will greatly improve our knowledge of how mountain building has driven climate changes under the influence of the convergent tectonic setting (i.e. India-Asia collision).

It has been shown that the isotopic composition of authigenic minerals from terrestrial sedimentary sequences adjacent to mountain belts may record the surface elevation of the windward mountain ranges (Dettman and Lohmann, 2000; Garzione et al., 2000; Ingraham and Taylor, 1991; Poage and Chamberlain, 2001; Sammel and Craig, 1981 ; Siegenthaler and Oeschger, 1980) . The Tianshan range is sandwiched between two large intracontinental basins -the Tarim Basin to the south and the Junggar Basin to the north (Figure 1a). The Tianshan piedmonts are incised by several large rivers that provide the exposure of continuous Tertiary sections suitable for the analysis of syn-orogenic sediments shed from the range. Two sedimentary sections located in the Dushanzi area in the northern piedmont (Figure 1b), named Kuitun $\mathrm{He}$ and Jingou $\mathrm{He}$ ("He" means river in Chinese), have been dated by magnetostratigraphic analysis (Charreau et al., 2009a; Charreau et al., 2005), providing robust constrains on the depositional ages of $\sim 23.6$ to $1 \mathrm{Ma}$ in the Jingou He section, and $\sim 10.5$ to 3.1 $\mathrm{Ma}$ in the Kuitun He section (Figure 2), and enabling the derivation of the accumulation rates shown in Figure 3d. In this paper, we present oxygen and carbon isotopic compositions of pedogenic and lacustrine carbonates from both sections, and then we discuss the late Cenozoic evolution of the palaeotopography of the range. These data represent the first isotopic record at this latitude north of the Tibetan Plateau, with a time-constrained, high sampling resolution.

\section{Sedimentology}


In the Jingou He and Kuitun He sections, five lithostratigraphic formations can be recognized including the Anjihai, Shawan, Taxi He, Dushanzi and Xiyu Formations (BGMRX, 1985). Based on a sedimentological analyses in the Jingou He section, Charreau et al. (2009a) have better defined these formations in terms depositional systems (Fig. 3). Updated descriptions and interpretations of the depositional processes and environments in the Jingou He sections as well as a new sedimentologic analysis of Kuitun He section are briefly presented below. In both sections we used a standard faciological method: facies were defined on the basis of their lithology, sedimentary structures and biological remains and then interpreted in terms of depositional processes using facies associations (individual facies in fluvio-lacustrine sediments solely depend on the sediment nature or on hydrodynamic processes). Those facies associations, which appear in specific locations along the studied sections, were used to divide the sedimentary series in several units with different depositional environmental characteristics.

Jingou He section

In the Jingou He section, Charreau et al. (2009a) identified 12 depositional units linked to different depositional systems (Fig. 3). Descriptions of these units and interpretations in term of depositional environments are briefly presented and updated below, from the bottom to the top of the section.

Units 1 and 2 are made up of dark grey silty marls, calcareous mudstones and packstones, and minor sandstones with sharp bases. Within these units, deposits display wave ripples, freshwater shells, vertebrate bones, and burrows. Upward, unit 3 consists of red clayey siltstones, sandstones with frequent silt-rich laminae, and sandstones to microconglomerates with erosive bases. Unit 4 consists of red siltstones, sandstones with sharp bases, and sandstones to conglomerates with erosive bases. These sediments contain root traces and carbonate nodules. Above unit 4, units 5 and 6 are composed of minor dark grey silty marls, red siltstones, sandstones with occasional silt-rich laminae, and sandstones to conglomerates with erosive bases. In these units, deposits show pervasive bioturbation alternately consisting of burrows and root traces. Like units 1 and 2, unit 7 includes dark grey silty marls, calcareous mudstones and packstones, and sandstones with sharp bases, as well as minor red clayey siltstones. In these facies, wave ripples, freshwater shells, and burrows are present. Upsection, units 8 and 9 consist of red siltstones, sandstones with occasional silt-rich laminae, and sandstones to conglomerates with erosive bases. These deposits also exhibit a pervasive bioturbation alternately consisting of 
burrows and root traces, as well as some dark grey silty marls (unit 8) or wave ripples (unit 9). Units 10 and 11 comprise orange fine-grained sandstones, sandstones to microconglomerates with sharp bases, and conglomerates with erosive bases. In these units, root traces and carbonate nodules are also present. Finally, at the top of the section, unit 12 consists of conglomerates with erosive bases, and minor sandstones to microconglomerates with sharp bases. However, this unit was not sampled since it contains no material suitable for isotopic analyses.

Therefore, in terms of depositional environments, we interpret units 1, 2 and 3 to have formed as a result of a first lacustrine depositional episode in a large and deep calcareous lacustrine system (units 1 and 2), progressively evolving to a shallow terrigenous one (unit 3). Then, unit 4 indicates the occurrence of a fluvial depositional period characterized by a gravelly fluvial system. Afterwards, units 5, 6, 7, 8 and 9 point to the existence of a second lacustrine episode with a progressive change of depositional environment from a fluvio-lacustrine system (units 5 and 6) to a large and deep calcareous lacustrine one (unit 7), and a fluvio-lacustrine system again (units 8 and 9). Finally, units 10 and 11 indicate the occurrence of a new period of gravelly fluvial deposition, whereas unit 7 records the later development of a gravelly alluvial fan system (Charreau et al., 2009b).

\section{Kuitun He section}

In the Kuitun He section, 7 depositional units can be identified. Descriptions of these units and interpretations in term of depositional environments are briefly presented below, from the bottom to the top of the section.

Unit 1 consist of dark grey silty marls with freshwater shells, red clayey siltstones, sandstones with occasional silt-rich laminae, and minor sandstones to microconglomerates with erosive bases. Unit 2 includes red siltstones, sandstones with sharp bases, and sandstones to microconglomerates with erosive bases. Within this unit, deposits display a pervasive bioturbation by burrows. Upward, units 3, 4, 5 and 6 are made up of red siltstones to orange fine-grained sandstones, sandstones to microconglomerates with sharp bases, and sandstones to conglomerates with erosive bases. In these units, root traces and carbonate nodules (unit 4,5 and 6) are present. At the top of the section, unit 7 consists of conglomerates with erosive bases, and minor sandstones to microconglomerates with sharp bases. One can notice that the sampling of 
the Kuitun He section begins within unit 4 and ends before unit 7, avoiding sampling material that is not suitable for isotopic analyses.

In terms of depositional environments, units 1 and 2 are interpreted to have been deposited in a lacustrine depositional episode, with a shallow terrigenous lacustrine system (unit 1) giving rise to a fluvio-lacustrine one (unit 2). Then, units 3, 4, 5 and 6 are interpreted to indicate the occurrence of a fluvial depositional period, during which a sandy fluvial system (unit 3 ) is replaced with a gravelly one (units 4, 5 and 6). Finally, unit 7 is interpreted as having been deposited in a gravelly alluvial fan system.

\section{Stable isotope analysis}

\section{Material and methods}

In this study, we have analyzed the oxygen and carbon isotope compositions of lacustrine carbonates as well as paleosol carbonate and carbonate cements from fluvial deposits. In fluvial sediments, the isotopic composition in $\mathrm{O}$ and $\mathrm{C}$ of both early calcareous cement and paleosol carbonate reliably record long-term changes in climate (Cerling, 1984) and/or surface elevation (Chamberlain and Poage, 2000; Dettman et al., 2003; Dettman and Lohmann, 2000; Garzione et al., 2004; Garzione et al., 2000; Poage and Chamberlain, 2001; Quade et al., 1989; Quade and Roe, 1999). 150 samples were collected in the Jingou section and 66 samples were collected in the Kuitun He section, both with an average sampling interval of $\sim 14 \mathrm{~m}$ (50-150 ka). Samples from lacustrine deposits include mostly carbonate-rich mudstone and marls. In the remaining section, samples were collected from appropriate material in fluvial floodplain deposits consisting mostly of paleosol nodular calcrete (e.g. Goudie, 1983) and carbonate-cemented fine sandstone and siltstone. Pedogenic carbonate, including calcrete and carbonate cement, both precipitate in sediments prior to the diagenesis (i.e. authigenic) and near the surface (Cerling, 1984). Sampling of pedogenic carbonates is preferred when available as they clearly result from carbonate supersaturation due to evaporation, evapotranspriration and lowering $\mathrm{p}\left(\mathrm{CO}_{2}\right)$ in arid to semi-arid climates (e.g. Cerling, 1984). Pedogenic carbonate includes siltstone to sandstone nodules rich in carbonate as well as calcareous pisolite. Possible repeated soil formation in the flood plain and its erosion by stream flow make it difficult to reconstruct the original depth of the soils from which pedogenic carbonate was sampled, though it might represent critical 
information for interpreting the isotopic data. Sampling was not possible in the conglomeratic Xiyu formation.

Samples were powdered using a dental drill, and 0.3 to $9 \mathrm{mg}$ of powdered sample was placed in a sealed reaction vessel to analyze the isotopic composition of the carbonates. The sealed vessels were flushed with helium, and then reacted with $100 \%$ phosphoric acid at $72^{\circ} \mathrm{C}$. Carbon dioxide was then sampled from vessels using a Finnigan Gas-Bench, oxygen and carbon isotope ratios were measured by a Finnigan MAT Delta+ XL mass spectrometer at the Stanford University Stable Isotope Biogeochemistry Laboratory. Repeated analysis of NBS-19 and Merck standards shows that laboratory precision for both carbon and oxygen isotope ratios is $<0.2 \%$. The complete list of sample with their stratigraphic position, type of carbonate (lacustrine, pedogenic or cement), age and isotopic composition is given as online depository data (Table A).

To better characterize the nature of vegetation type (C3 vs. C4 plants), complementary analyses were carried out on a bovid fossil tooth. This tooth was sampled from the Jingou He section within the Dushanzi Formation, from a lower right jaw with two molars belonging to a bovid identified as Hyspodontus sp. (Charreau et al., 2009a). $24.5 \mathrm{mg}$ of enamel from one molar was powdered and analysed at the Stable Isotope Laboratory of the Centre de Recherche Pétrographique et Géochimique (Nancy, France). The powder was reacted with $\mathrm{H}_{3} \mathrm{PO}_{4}(100 \%)$ at $25^{\circ} \mathrm{C}$ (Gajurel et al., 2006) and the carbon and oxygen isotopic ratios of the $\mathrm{CO}_{2}$ were analyzed using a modified EuroEA3028-HT elemental analyzer coupled to a GV Instruments IsoPrime Continuous-flow Isotope Mass Spectrometer.

Results

$\delta^{18} \mathrm{O}$ values of carbonate samples range from 13.7 to $29.9 \%$ in the Jingou He section, with an average of $20.9 \pm 2.3 \%$ (Fig. 3). Samples in the Kuitun He section range from 16.3 to $21.0 \%$, with an average of $18.9 \pm 0.9 \%$. $\delta^{13} \mathrm{C}$ values in the Jingou He section range from -12.9 to $3.0 \%$ with an average of $-6.7 \pm 2.29 \%$, and in the Kuitun He section range from -7.8 to $-4.0 \%$, with an average of $-6.1 \pm 0.9 \%$. In samples from fluvial systems, pedogenic calcareous pisolite and the other carbonates (cement and nodule) have similar isotopic composition, with average $\delta^{18} \mathrm{O}$ values of $20.0 \pm 2.0 \%$ and $20.3 \pm 1.1 \%$, and $\delta^{13} \mathrm{C}$ values of $-6.9 \pm 1.4 \%$ and $-6.5 \pm 0.8 \%$, 
respectively. The average isotopic composition of lacustrine carbonate (Jingou He section) is significantly different from that of fluvial samples, with average $\delta^{18} \mathrm{O}$ values of $24.8 \pm 2.0 \%$ and $\delta^{13} \mathrm{C}$ values of $-1.5 \pm 3.8 \%$. Though isotopic values of both carbon and oxygen show significant variability throughout the section, one may observe long-term trends. From $\sim 24$ to $\sim 22-23 \mathrm{Ma}$, $\delta^{18} \mathrm{O}$ and $\delta^{13} \mathrm{C}$ values covary and decrease by $\sim 5 \%$ in both cases. From $\sim 23-22$ to $\sim 16-15 \mathrm{Ma}$, oxygen and carbon isotopic compositions remain relatively constant, with the exception of an increase in both oxygen and carbon isotopic values $\sim 16-17 \mathrm{Ma}$. From $\sim 10-11 \mathrm{Ma}$ on, $\delta^{13} \mathrm{C}$ average values progressively increase from $-6.7 \pm 0.8 \%$ to $-5.6 \pm 1.1 \%$ but values could be considered as steady if one consider the large uncertainties. $\delta^{18} \mathrm{O}$ values remains relatively stable during this period. At the transition zone between the sections, from $\sim 10$ to $8 \mathrm{Ma}$, oxygen isotopic values average $20.5 \pm 1.7 \%$, significantly different from the Jingou He section, where sample values are an average of $18.8 \pm 0.7 \%$ during the same period of time.

The Hysondontus sp. molar shows very similar isotopic composition to pedogenic and cement carbonate samples from the same time period, with $\delta^{18} \mathrm{O}$ values of $19.6 \%$, and $\delta^{13} \mathrm{C}$ values of $-7.21 \%$.

\section{Discussion}

Several competing factors may explain variations in isotopic composition of authigenetic minerals in soils, including precipitation composition, mean annual temperature, seasonality of precipitation, continentality, source of air mass, global volume of the ice sheets, and surficial

processes such as water-rock interaction and evaporation. The magnitude of these effects must be examined in order to assess the role of surface elevation change in the isotopic records.

\section{Diagenesis}

Dissolution/recrystallization processes during diagenesis can significantly alter the isotopic signal originally recorded in carbonate, especially in the case of sandstone cement (Garzione et al., 2004; Quade and Roe, 1999; Sanyal et al., 2005). As sediments are buried at depth, increased temperature and dissolution/recrystallization processes can change the isotopic composition of carbonates (Garzione et al., 2004; Quade and Roe, 1999; Sanyal et al., 2005). This diagenesis may also generate a large spread of isotopic compositions as dissolution/recrystallization occurs at different depths and stages of burial (Sanyal et al., 2005). 
However, fission track analyses of Cenozoic strata in the Manas section, just $\sim 20 \mathrm{~km}$ west of the Jingou He section, show that sediments have not been buried at depth greater than $\sim 2 \mathrm{~km}$ (Hendrix et al., 1994). Moreover, in both sections few samples have the extremely low oxygen isotopic values $(<15 \%)$ often characteristic of diagenesis overprint in the literature, the spread of the isotopic composition is relatively low (1-2\%), and no trends related to depth can be seen as observed in the Surai section (Nepal) where a diagenesis impact have been observed (Sanyal et al., 2005). Moreover, in sections where samples of pedogenic carbonate and carbonate cement occur together, their values are similar, suggesting instead both types of carbonate were formed near surface from water that infiltrated the flood plain. Finally, while isotopic re-equilibration with diagenetic fluids can cause mudstone $\delta^{18} \mathrm{O}$ values to be more negative than skeletal remains (Dickson and Coleman, 1980), the $\delta^{18} \mathrm{O}$ values of the Hypsondontus Sp. teeth are similar or even more negative than that of the mudstone, suggesting no re-equilibration with diagenetic fluids.

\section{Allogenic carbonate}

Detrital carbonate can also contribute to the isotopic composition of authigenic carbonate. However, the geology of the present day Kuitun and Jingou river catchment areas are mainly composed of non-carbonate metamorphic (e.g. metapelites) and igneous rocks (e.g. granites, Fig. 4) that were derived from an island arc collision during the Carboniferous to Permian (e.g. Charvet et al., 2007; Gao et al., 1998; Wang et al., 2008a; Windley et al., 1990). However, scarce Carboniferous to Devonian limestones interbedded with volcanic breccias are described by the BGMRX (1985) in the Kuitun He drainage basin (Fig. 4). A significant allogenic contribution would have increased $\delta^{18} \mathrm{O}$ values in the Kuitun $\mathrm{He}$ section as compared to the Jingou He section. However, the opposite is true (Fig. 3). Moreover, carbonate represents less than $15 \%$ of the total watershed area (Fig. 4). The heavy mineral compositions of sediments in both sections show no significant variation in composition for the last $20 \mathrm{Ma}$ (Gallaud, 2008), which suggests the geology of the drainage basin has remained relatively constant, and thus is probably similar to that observed today. We therefore conclude that Carboniferous allogenic material did not significantly contribute to the isotopic composition of analyzed carbonates.

Early Cenozoic to Mesozoic Junggar foreland deposits are mainly fluvio-lacustrine in origin and could also include pedogenic carbonates. Consequently, as the deformation propagated through the piedmont, those carbonates may have been uplifted, eroded, and then 
redeposited in the basin during the late Cenozoic. Nevertheless, recent structural studies in the Dushanzi area have shown that folding and faulting probably started around $10 \mathrm{Ma}$ or later. Recently $(<1 \mathrm{Ma})$, uplift rates across the folds have exceeded sedimentation rates enabling the emergence at the surface of the different structures and strata (Dushanzi anticline, Huerguosi anticline, see Fig. 1), and therefore their erosion (Charreau et al., 2008; Daëron et al., 2007). In the studied section, the proportion of reworked pedogenic carbonate from earlier foreland deposits is thus probably low.

\section{Evaporation}

In continental settings, $\delta^{18} \mathrm{O}$ values of carbonate can be significantly impacted by evaporative processes that may alter the isotopic composition of water. The nature of the depositional environment and its aridity are thus key parameters that may influence the isotopic composition of carbonate. To better discuss the possible influence of evaporation on our isotopic record, we have plotted for both sections the isotopic composition against the depositional environment and grain size (Fig. 5), and the depositional environment against $\delta^{18} \mathrm{O}$ and $\delta^{13} \mathrm{C}$ values (Fig. 3).

\section{Lacustrine carbonates}

Evaporative processes are particularly prevalent in lakes, where the residence time of water and therefore evaporation is strongly controlled by the mean or seasonal temperature and opening/closing processes of the lake (Carroll and Bohacs, 1999; Dettman et al., 2003). From figures 3 and 5 one can see that the more positive values of both $\delta^{18} \mathrm{O}$ and $\delta^{13} \mathrm{C}$ values, as well as the greatest variability, are associated with lacustrine environments, especially deep calcareous reducing lake environments. More positive values mainly correspond to samples composed of calcareous mudstone, which typically precipitates during summer when water temperature is warmer hence with stronger evaporation (Drummond et al., 1995), and the isotopic compositions of rain is most likely more positive (Araguas-Araguas et al., 1998; see for example the isotopic composition of rain in the town of Urumqi during summer, Figure 1a). Therefore, the two spikes 
in both $\delta^{18} \mathrm{O}$ and $\delta^{13} \mathrm{C}$ values at $\sim 16$ and $\sim 24$ Ma probably owe their origin to strong evaporative effects and summer precipitation during lacustrine deposition, consistent with our sedimentological analysis which, indeed, attests the presence of lake deposits at this time (Fig. 3). One can also note a possible co-variance of carbon and oxygen isotope values during deep lacustrine periods, especially from $\sim 24$ to $\sim 22-23 \mathrm{Ma}$ (See Fig A in supplementary data for a plot of $\delta^{13} \mathrm{C}$ against $\delta^{18} \mathrm{O}$ of sedimentary unit 1). Isotopic co-variance is commonly associated to hydrologically closed lake where the time residence of water is long and the inflow-evaporative balance dominate the isotopic composition (Talbot, 1990). This is consistent with the sedimentary analysis, which shows that during this period of time the sedimentary environment was a deep calcareous reducing lake with no significant detrital input. The fact that $\delta^{18} \mathrm{O}$ and $\delta^{13} \mathrm{C}$ values significantly decrease from $\sim 24$ Ma to $\sim 22-23$ Ma may represent a change of the mean temperature, or a modification of the environment from a closed lake to a lake progressively opened to external inputs. The sedimentological record supports this scenario, with a shift in sedimentary environment from a calcareous deep reducing lake (unit 1 on Fig. 3a) to a shallower carbonaceous reducing lake with inputs of terrigenous sediments (Charreau et al., 2009a).

\section{Pedogenic and cement carbonates in fluvial deposit}

Like lake sedimentary deposits, paleosols are also sensitive to evaporative effects (Garzione et al., 2006; Rowley and Currie, 2006). In fluvial floodplain deposits, the presence or lack of pedogenic carbonate and bioturbation may reveal the aridity of the environment (see Fig. 3 and the sedimentological part). We did not see any correlation between the sedimentologically interpreted aridity of the flood plain and its isotopic composition (Figs. 3 and 5), suggesting that evaporation had no great impact on isotopic records during purely fluvial periods. However, we acknowledge that a spread in composition (1-2\% on average) exists but it remains low and 
probably owes its origin to seasonal variation in temperature rather than evaporation which we argue is limited (Garzione et al., 2006; Rowley and Currie, 2006).

\section{Paleoclimate}

The oxygen and carbon isotopic composition of waters recorded in fluvial pedogenic carbonate minerals in Junggar Basin sedimentary sections may provide valuable information on the airmass circulation in central Asia and the nature of vegetation at the time of their deposition, and therefore insights on the paleoclimate evolution in the northern Tianshan.

\section{Origin of the Air Mass}

In both the Kuitun $\mathrm{He}$ and Jingou He sections, $\delta^{18} \mathrm{O}$ values of pedogenic carbonate are, on average, 1-3\% lower than those in similar studies carried out in Central Asia over the same period of time to the south in the Tarim and Qaidam basins (Graham et al., 2005; Kent-Corson et al., 2009). This may reflect the flow of airmasses (Araguas-Araguas et al., 1998) from the southeast (becoming increasingly isotopically negative as it travels overland). However, the high oxygen isotopic values measured from Tarim and Qaidam Basins may be the result of significant evaporative effects (Kent-Corson et al., 2009). We calculated isotopic composition of water in isotopic equilibrium with the carbonate measured in our study using the equation of Friedman and O'Neil (1977). Given a range of temperature from $5^{\circ} \mathrm{C}$ to $30^{\circ} \mathrm{C}$ (to account for the strong seasonal variations in temperature possible in such intracontinental settings, see Fig. 1), meteoric water values (Table 1 ) could have ranged from $-14.2 \pm 0.8 \%$ to $-8.3 \pm 0.8 \%$ and $-12.8 \pm 2.4 \%$ o to $7.2 \pm 2.4 \%$ in the Kuitun $\mathrm{He}$ and Jingou He sections, respectively. These values, although estimates, are nevertheless comparable to the average $\delta^{18} \mathrm{O}$ values of modern precipitation measured in Urumqi (Fig. 1) and in other meteorological stations in Central Asia north of the Tianshan mountains where the $\delta^{18} \mathrm{O}$ values of meteoric water are in average lower than $-8 \%$ are linked to the Arctic and Westerly Airmasses (Araguas-Araguas et al., 1998). In contrast, south of the Tianshan, the $\delta^{18} \mathrm{O}$ values of meteoric water are, in average, greater than $-8 \%$ o where the majority of the airmass reaching the region comes from Southeast Asia. Comparison with $\delta^{18} \mathrm{O}$ values of modern precipitation is not straightforward, especially when strong seasonal variation in composition exist (Fig. 1a). Nevertheless, this does support our interpretation that the water from which carbonate precipitated was probably meteoric. The climate and source of airmasses 
during the time this sedimentary record was deposited were likely similar to today, derived primarily from the Arctic and Westerly Airmasses (Araguas-Araguas et al., 1998).

\section{C3 vs. C4 plants}

The carbon isotope composition of carbonate in paleosol nodules and cement can be used to infer the isotopic composition of vegetation and the relative abundance of $\mathrm{C} 3$ versus $\mathrm{C} 4$ plants present during the soil formation (Cerling et al., 1989; Quade et al., 1989; Quade and Roe, 1999). In the Junggar sections, the isotope compositions have average $\delta^{13} \mathrm{C}$ values of $\sim-6$ to $-7 \%$. Values remain relatively stable from $\sim 24 \mathrm{Ma}$ to $\sim 10 \mathrm{Ma}$ and then increase gradually until $\sim 5 \mathrm{Ma}$. Paleosol carbonate precipitated in equilibrium with $\mathrm{CO}_{2}$ derived from solely $\mathrm{C} 3$ plants has $\delta^{13} \mathrm{C}$ values that range from -9 to $-13 \%$, and carbonate precipitated in equilibrium with solely $\mathrm{C} 4$ plants will result in $\delta^{13} \mathrm{C}$ values that range from 1 to 3\% (Cerling and Quade, 1993). Our results are intermediate between these two end-members, and we propose several interpretations. The average $\delta^{13} \mathrm{C}$ value of $\sim-6$ to $7 \%$ could be due to: (1) the presence of both $\mathrm{C} 3$ and $\mathrm{C} 4$ plants, (2) the isotopic signature of $\mathrm{C} 4$ plants living at altitude where lower $\mathrm{p}\left(\mathrm{CO}_{2}\right)$ causes the carbon isotopic values of carbonates to be more negative (e.g. Körner et al., 1991) (3) a mostly C3dominated landscape with hydric stress caused by high seasonality in precipitation increasing the carbon isotopic values recorded in carbonates (4) much drier conditions and lower C3 plant cover resulting in low soil respiration rates, in which the ratio of plant-derived $\mathrm{CO}_{2}$ to atmospheric $\mathrm{CO}_{2}$ is low. To better characterize the paleo-vegetation we have carried out complementary $\mathrm{C}$ and $\mathrm{O}$ isotopic analyses on one of the Hypsodontus fossil tooth found in the Jingou He section at $\sim 12 \mathrm{Ma}$ (as its isotopic composition should result from the composition of the animal diet). The tooth $\delta^{13} \mathrm{C}$ value $(-7.2 \%)$ is very similar to the average $\delta^{13} \mathrm{C}$ values of carbonates $\left(-6.7 \pm 2.3 \%\right.$ ). Yet, the ${ }^{13} \mathrm{C}$ fractionation between plants and teeth of large ruminant mammals is $\sim+14 \%$, very similar to the +15\% between plants and soil carbonate (Cerling and Harris, 1999; Koch, 1998). Therefore, we may assume that, in the Junggar basin, the $\delta^{13} \mathrm{C}$ values of carbonates indeed reflect the $\mathrm{CO}_{2}$ derived from the decomposition of plants and was not impacted by atmospheric $\mathrm{CO}_{2}$. However, this remains true only when this particular bovid lived at $\sim 12 \mathrm{Ma}$ and must be handled with caution as only one fossil was analyzed. Moreover, the altitude of the depositional area is too low $(<900 \mathrm{~m})$ to significantly impact the $\mathrm{pCO}_{2}$ (Körner et al., 1991). Another possible 
explanation is that the presence of mixed $\mathrm{C} 3$ and $\mathrm{C} 4$ plants explains these intermediate $\delta^{13} \mathrm{C}$ values. Deng and $\mathrm{Li}$ (2005) and latter Wang et al. (2008b) analyzed the C and O isotopic composition of 51 and $54 \mathrm{C} 3$ plants collected on the Tibetan plateau and surrounding areas, respectively. They found similar results with mean $\delta{ }^{13} \mathrm{C}$ values of $-25.3 \%$ and $-25.7 \%$, respectively. Therefore, despite the high altitude, strong seasonality, dry conditions, and hydric stress on the Tibet Plateau, these results fall outside of the range of expected C3 plants isotopic composition. Even if paleoenvironmental conditions similar to the present Tibet existed in the northern Tianshan the potential impact on the carbonate values was probably too small to explain the observed intermediate $\delta^{13} \mathrm{C}$ values.

The average $\delta^{13} \mathrm{C}$ values of $\sim-6$ to $-7 \%$ could result from a mixed $\mathrm{C} 3$ and $\mathrm{C} 4$ biomass. However, according to much of the literature, the expansion of $\mathrm{C} 4$ plants occurred worldwide either in the late Miocene ( 6-8 Ma) or younger (e.g. Cerling et al., 1997; Cerling et al., 1989; Molnar, 2005; Quade and Cerling, 1995; Quade et al., 1989), and the finding of C4 plants at 12 Ma would be unexpected. Unlike these records, if we do observe an increase of $\delta^{13} \mathrm{C}$ values from $\sim-7 \%$ to $\sim-5.8 \%$, and from $\sim 10$ Ma to $\sim 5 \mathrm{Ma}$, respectively (Fig. 3), given the large uncertainties the expansion of $\mathrm{C} 4$ plants in this area during these time periods remains questionable. If there was an expansion of $\mathrm{C} 4$ plants in this region, it would have been very gradual and not sudden as seen elsewhere. This suggests that the expansion of $\mathrm{C} 4$ plants had a negligible influence on the isotopic record that we measured, though we recognize our record does not extend much past $6 \mathrm{Ma}$. The expansion of $\mathrm{C} 4$ plants has been attributed to a global decrease of atmospheric carbon dioxide levels in the late Miocene ( 6-8 Ma) (Cerling et al., 1997; Cerling et al., 1989). However, several recent studies carried out in Central Asia suggest that in this region the appearance of $\mathrm{C} 4$ plants was not synchronous and probably controlled by regional environmental change to strengthened seasonality (Quade et al., 1989). In the Linxia basin from 13.1 to 4.3Ma, Fan et al. (2007) found very negative values of $\delta^{13} \mathrm{C}$ in organic carbon ( -24 to $-29 \%$ ) which suggest that terrestrial C4 plants were ether absent or insignificant in this region. From the analysis of 91 tooth enamel samples from Inner Mongolia, Zhang et al. (2009) concluded that they were no $\mathrm{C} 4$ plants prior to $8 \mathrm{Ma}$ in this region. Farther to the east, Wang and Deng (2005) concluded from a similar analysis that the presence of $\mathrm{C} 4$ grasses were only significant after 2.5 Ma. In northern China during late Miocene, several authors have pointed out 
a migration of the forest-steppe-desert environment yielding diachronous records of the $\mathrm{C} 3-\mathrm{C} 4$ transition (Passey et al., 2009; Suarez et al., 2011). The presence of C4 plants at $12 \mathrm{Ma}$ in the northern Tianshan is consistent with the diachroneity of the C3-C4 transition in Central Asia. Nevertheless, this interpretation would be contingent on further study, including study of organic matter from the study areas.

\section{Paleoaridity}

The increase of $\delta^{13} \mathrm{C}$ values between $\sim 10 \mathrm{Ma}$ and $\sim 5 \mathrm{Ma}$ (Fig. 3) is most likely not related to a progressive switch from $\mathrm{C} 3$ to $\mathrm{C} 4$ plants, and may have several origins. It could be related to elevation changes of the foreland due to tectonics, changes in the depositional environment unfavorable to the vegetation growth (e.g. a progressive shift from gravely fluvial system with coarse flood plain toward the alluvial fan system of the Xiyu formation), or environmental changes (temperature, rainfall) that drive aridity or seasonality and hence the plant respiration rate. Isotopic and sedimentary studies to the south of this study area do show evidence for intensified aridity in Qaidam Basin beginning at 12 Ma (Zhuang et al., 2011), and in the Tarim and Qaidam Basins (with less age control) broadly in the Neogene (Kent-Corson et al., 2009). Two pollen analyses have been carried out in the Northern Tianshan and give contrasting results. In the Dushanzi section (located 5km east of the Kuitun He section), Sun et al. (2007) stated that "a dry climate has occurred in the inland basins of northwestern China at least since $8.7 \mathrm{Ma}$ ago" though "a warm and humid phase occurred at 5.8-3.9 Ma ago". However, a similar study of the Taxi section, located less than $100 \mathrm{~km}$ east of the Dushanzi section, Sun and Zhang (2008) suggested that "a change to an arid climate occurred at $6 \mathrm{Ma}$ ". In our study areas, the sedimentary record does not support any increased aridity since $10 \mathrm{Ma}$ in both sections. Therefore, no strong evidence yet exists in terms of how enhanced aridity may have played a factor in the progressive increase of $\delta^{13} \mathrm{C}$ values seen in this study.

\section{Paleotopography}

\section{Foreland}

A relationship between the isotopic composition of both $\mathrm{C} 3$ and $\mathrm{C} 4$ plants and elevation exists and could be related to a decrease in atmospheric $\mathrm{p}\left(\mathrm{CO}_{2}\right)$ with elevation (Bird et al., 1994; Farquhar, 1989; Körner et al., 1991; Tieszen, 1991; Wang et al., 2008b). The average altitudinal 
decrease in $\delta^{13} \mathrm{C}$ values range from $0.8 \%$ to $2.7 \%$ per kilometer with an average of $1.1 \%$ (Körner et al., 1991). Therefore, an average change of $\sim 1.2 \%$ in $\delta^{13} \mathrm{C}$ values of carbonate, as observed from 10 to $4 \mathrm{Ma}$ (Fig. 3), would imply an elevation change bracketed between $1500 \mathrm{~m}$ and $400 \mathrm{~m}$. This would represent the elevation change of the depositional area only, where vegetation influences soil formation, and not of the whole Kuitun He and Jingou He drainage basins that will be discussed below. This interpretation is consistent with recent structural analyses showing that the Huerguosi anticline and the Anjihai folds (Figure 1) probably started to growth at $\sim 8-10 \mathrm{Ma}$ (Charreau et al., 2008; Daëron et al., 2007), when $\delta^{13} \mathrm{C}$ values begins to rise. Consequently, during this period of tectonic activity the elevation of the southern Junggar Basin may have progressively risen while the altitude in the drainage basin may have remained relatively steady. This may be due to the propagation of the deformation to the north into the present piedmont. However, the amount of shortening estimated in this piedmont (Avouac et al., 1993) seems too small to generate a $>1 \mathrm{~km}$ of uplift. Since $\sim 10 \mathrm{Ma}, \sim 2 \mathrm{~km}$ of sediments were deposited in the foreland basin. Despite subsidence, due to the closed endoreic setting of the Junggar basin, this progressive sediment filling may have also contribute to the change in altitude. Since $\sim 10 \mathrm{Ma}$, sediments prograde into the basin (e.g.Charreau et al., 2009b) in both sections, where depositional environments progressively evolved from a fluvial systems, with coarse-grained flood plains, to a braided alluvial fan system (Fig. 3 and Charreau et al., 2009b). This implies the development of a new depositional environment unfavorable to vegetation growth, and therefore, probably, a decrease in plants' influence on soil carbonate $\delta^{13} \mathrm{C}$ values. Thus, elevation change in the piedmont $(<1 \mathrm{~km})$, sedimentary filling $(<2 \mathrm{~km})$ and the establishment of a more integrated drainage system unfavorable to the development of plants (i.e. alluvial fan), could have contributed to the progressive decrease in $\delta^{13} \mathrm{C}$ values observed from $\sim 10$ to $\sim 4 \mathrm{Ma}$.

\section{Drainage basin in the high range}

It is significant that when sections overlap in time (e.g. 10.5 Ma to $\sim 7.5 \mathrm{Ma}$ ), the $\delta^{18} \mathrm{O}$ values are on average lower by $\sim 1.7 \%$ in the Kuitun He section than in the Jingou He. The two sedimentary sections are both located in the Northern piedmont and only $\sim 60 \mathrm{~km}$ apart, in a very similar context: similar altitude with low surrounding reliefs and under the same atmospheric 
influence. Global effects such as difference in source of airmass and climate can likely be discounted. Amount of precipitation, moisture, or mean annual temperature are also likely the same. As seen above, this difference is not likely to be the results of lithological variations in the drainage basins and detrital inheritance. The $\delta^{18} \mathrm{O}$ values of soil carbonate are usually in equilibrium with water coming from local rainfall that infiltrated the soil and not from flowing water (e.g. Quade et al., 2011). But again, as the two sections are located only $\sim 60 \mathrm{~km}$ apart, and are in a similar context, the isotopic composition of rainfall water was probably the same in the two areas. Thus, in interpreting the difference in oxygen isotope values in carbonates from the two sections that overlap in time, two other possibilities remain. Either evaporative effects were stronger in the Jingou He area, or the soil carbonate composition was influenced by run-off water from distant parts of the catchment. Indeed if the hypsometric mean elevation of the Kuitun $\mathrm{He}$ drainage basin was higher it probably resulted in a more negative composition of meteoric water that could have flooded the soils and therefore yield to lower isotopic values of pedogenic carbonate. During this particular period of time the depositional environments were relatively similar in both sections and consist of fluvial/overbank deposits. The distance between sections was probably the same before shortening and deformation in the piedmont, and thus was low $(<60 \mathrm{~km})$. Therefore, we do not expect any strong difference in the environmental condition in the two areas. As outlined previously in this paper, we don't see any evidence that would support the significant influence of evaporative effects in these sections, and thus don't favor this as the driving mechanism for the difference in isotopic composition between the sections. We thus think that this difference is instead related to the topography and hypsometric elevation of the drainage basins (Rowley et al., 2001). The present day weighted mean elevation is similar in both basins with $2790 \mathrm{~m}$ and $2760 \mathrm{~m}$ for the Kuitun He and Jingou He watersheds respectively. However, the present topography of the Kuitun He drainage basins has a higher proportion $(\sim 15 \%)$ of high elevation (2-3 km) areas than in the Jingou He (Figure 6). Higher elevation in the Kuitun $\mathrm{He}$ drainage basin implies more isotopically depleted meteoric water, and hence more negative isotopic composition of pedogenetic carbonate in the Kuitun He section. Consequently, in the northern Tianshan the oxygen isotope composition of soil carbonates in the foreland may have been related in to the net elevation of the drainage basin within the high range. Yet, the longer-term trends of $\delta^{18} \mathrm{O}$ values remains relatively constant in both sections and no large change in oxygen isotope values is observed (in fluvial sediments only). This suggests a pre-existing topography 
that had been uplifted before $\sim 24 \mathrm{Ma}$. This interpretation is coherent with recent studies. From fission tracks dating of Mesozoic sandstone located in the northern piedmont, Hendrix et al. (1994) suggested that the deformation in the Tianshan piedmont started at about $24 \mathrm{Ma}$, implying that deformation within the high range started earlier, which is consistent with thermal modeling on magmatic apatite carried out by Dumitru et al. (2001) and Jolivet et al. (2010). Analysis of accumulation rates in the Junggar and Tarim basins suggest that the Tianshan probably underwent pulses of rock uplift at $\sim 15 \mathrm{Ma}$ and $\sim 11$ Ma balanced by erosion (Charreau et al., 2009a; Charreau et al., 2005; Charreau et al., 2006) suggesting that the deformation and the formation of topography were sustained until today.

\section{Conclusion}

Isotopic analyses of non-marine sediments combined with precise magnetostratigraphic dating may provide a detailed and high-resolution record of paleotopographic and climate changes. Our data represent the first long term and high-resolution record at this latitude north of the Tibetan Plateau and should be of interest in reconstructing the tectono-climatic history of Central Asia, a key area in better understanding the evolution of the Tibetan Plateau after the India-Asia collision. Based on this study in the Junggar Basin, we conclude that the oxygen isotope composition of carbonate was mainly controlled by the hypsometry of the drainage basin and consequently that the topography in the northern Tianshan has remained relatively stable over the last $24 \mathrm{Ma}$. Our analysis shows that the carbon isotope record is mainly driven by the isotopic composition of plants at the time of deposition, suggesting no expansion of $\mathrm{C} 4$ plants at the late Miocene in this study area.

\section{Acknowledgements}

This study was financed by the French CNRS ANR. Fruitful discussions with C. Page Chamberlain were very useful for interpreting this record. We thank Jay Quade, Carmala Garzione and an anonymous reviewer for their critical reviews that greatly improved the quality of the manuscript. This is CRPG contribution $\mathrm{n}^{\circ} \mathrm{XXXX}$. 


\section{References}

Abdrakhmatov, K.Y., Aldazhanov, S.A., Hager, B.H., Hamburger, M.W., Herring, T.A., Kalabaev, K.B., Makarov, V.I., Molnar, P., Panasyuk, S.V., Prilepin, M.T., Reilinger, R.E., Sadybakasov, I.S., Souter, B.J., Trapeznikov, Y.A., Tsurkov, V.Y., and Zubovich, A.V., 1996, Relatively recent construction of the Tien Shan inferred from GPS measurements crustal deformation rates: Nature, v. 384, p. 450-453.

Araguas-Araguas, L., Froehlich, K., and Rozanski, K., 1998, Stable isotope composition of precipitation over southeast Asia: Journal of Geophysical Research v. 103, p. 28,721-28,742.

Avouac, J.-P., and Burov, E.B., 1996, Erosion as a driving mechanism of intracontinental mountain growth: Journal of Geophysical Research, v. 101, p. 17747.

Avouac, J.-P., Tapponnier, P., Bai, P., You, M., and Wang, G.A., 1993, Active Thrusting and folding along the northern Tien Shan and late Cenozoic rotation of the Tarim relative to Dzungaria and Kazakhstan: Journal of Geophysical Research, v. 98, p. 11.791-11.808.

Beaumont, C., Quinlan, G., and Hamilton, J., 1988, Orogeny and stratigraphy: Numerical models of the Paleozoic in the eastern interior of the North America: Tectonics, v. 7, p. 389-416.

Bird, M.I., Haberle, S.G., and Chivas, A.R., 1994, Effect of altitude on the carbon-isotope composition of forest and grassland soils from Paqua New Guinea: Global Biogeochemical Cycles, v. 8, p. 13-22.

Burbank, D.W., 1992, Causes of recent Himalaya uplift deduced from depositional patterns in the Ganges basin: Nature, v. 257, p. 680-683.

Bureau of the Geological and the Mineral Resources of the Xinjiang Uygur Autonomous Region, 1985, Geological map of the Xinjiang Uygur Autonomous Region, China, China Geological Printing House.

Carroll, A.R., and Bohacs, K.M., 1999, Stratigraphic classification of ancient lakes: Balancing tectonic and climatic controls: Geology, v. 99-102.

Cerling, T.E., 1984, The stable isotopic composition of modern soil carbonate and its relationship to climate: Earth and Planetary Science Letters, v. 71, p. 229-240.

Cerling, T.E., and Harris, J.M., 1999, Carbon isotope fractionation between diet and bioapatite in ungulate mammals and implications for ecological and paleocological studies: Oecologia, v. 120, p. 347-363.

Cerling, T.E., Harris, J.M., MacFadden, B.J., Leakey, M.G., Quade, J., Eisenman, V., and Ehleringer, J.R., 1997 , Global vegetation change through the Miocene/Pliocene boundary: Nature, v. 389, p. 153158.

Cerling, T.E., and Quade, J., 1993, Stable carbon and oxygen isotopes in soil carbonates,, in Swart, P., ed., Continental indicators of climate, Proceedings of Chapman Conference, Jackson Hole, Wyoming, American Geophysical Union Monograph, p. 217-231. 
Cerling, T.E., Quade, J., Wang, Y., and Bowman, J.R., 1989, Carbon isotopes in soils and paleosols as ecology and paleoecology indicators: Nature, v. 341, p. 138-139.

Chamberlain, C.P., and Poage, M.A., 2000, Reconstructing the paleotopography of moutains belts from Isotopic composition of authigenic minerals: Geology, v. 28, p. 115-118.

Charreau, J., Avouac, J.-P., Chen, Y., Dominguez, S., and Gilder, S., 2008, Miocene to present kinematics of fault-bend folding across the Huerguosi anticline, northern Tianshan (China), derived from structural, seismic, and magnetostratigraphic data: Geology, p. 871-874

Charreau, J., Blard, P.-H., Puchol, N., Avouac, J.-P., Lallier-Vergès, E., Bourlès, D., Braucher, R., Gallaud, A., Finkel, R., Jolivet, M., Chen, Y., and Roy, P., 2011, Paleo-erosion rates in Central Asia since 9 Ma: A transient increase at the onset of Quaternary glaciations? : Earth and Planetary Science Letters, v. 304, p. 85-92.

Charreau, J., Chen, Y., Gilder, S., Barrier, L., Dominguez, S., Augier, R., Sen, S., Avouac, J.-P., Gallaud, A., Graveleau, F., and Li, Y., 2009a, Neogene uplift pulses of the Tianshan mountains observed in the magnetic record of the Jingou River section (Northwest China): Tectonics, v. 28, p. doi:10.1029/2007TC002137

Charreau, J., Chen, Y., Gilder, S., Dominguez, S., Avouac, J.-P., Sevket, S., Sun, D., Li, Y., and Wang, W.-M., 2005, Magnetostratigraphy and rock magnetism of the Neogene Kuitun He section (northwest China) : implications for Late Cenozoic uplift of the Tianshan mountains: Earth and Planetary Science Letters, v. 230, p. 177-192.

Charreau, J., Gilder, S., Chen, Y., Dominguez, S., Avouac, J.-P., Sevket Sen, Jolivet, M., Li, Y., and Wang, W., 2006, Magnetostratigraphy of the Yaha section, Tarim Basin (China): 11 Ma acceleration in erosion and uplift of the Tianshan Mountains: Geology, v. 34, p. 181-184.

Charreau, J., Gumiaux, C., Avouac, J.-P., Augier, R., Chen, Y., Barrier, L., Gilder, S., Dominguez, S., Charles, N., and Wang, Q., 2009b, The Neogene Xiyu Formation, a diachronous prograding gravel wedge at front of the Tianshan: Climatic and tectonic implications: Earth \& Planetary Science Letters, v. 287, p. 283-310.

Charvet, J., Shu, L.S., and Laurent-Charvet, S., 2007, Paleozoic structural and geodynamic evolution of eastern Tianshan (NW China): welding of the Tarim and Junggar plates: Episodes, v. 30, p. 162186.

Cobbold, P.R., Davy, P., Gapais, D., Rossello, E.A., Sadybakasov, E., Thomas, J.C., Tondji Biyo, J.J., and de Urreiztieta, M., 1993, Sedimentary basins and crustal thickening: Sedimentary Geology, v. 86, p. 77-89.

Daëron, M., Avouac, J.-P., Charreau, J., and Dominguez, S., 2007, Modeling the shortening history of a fault-tip fold using structural and geomorphic records of deformation: Journal of Geophysical Research, v. 12, p. doi:10.1029/2006JB004460.

Deng, T., and Li, Y., 2005, Vegetational ecotype of the Gyirong Basin in Tibet, China and its response in stable carbon isotopes of mammal tooth enamel: Chinese Science Bulletin, v. 50, p. 1225-1229.

Dettman, D.L., Fang, X., Garzione, C.N., and Li, J., 2003, Uplift-driven climate change at 12 Ma: a long d180 record from the NE margin of the Tibetan plateau: Earth \& Planetary Science Letters, v. 214, p. 267-277.

Dettman, D.L., and Lohmann, K.C., 2000, Oxygen isotope evidence for high-altitude snow in the Laramide Rocky Mountains of North America during the Late Cretaceous and Paleogene: Geology, v. 28, p. 243-246.

Drummond, C.N., Patterson, W.P., and Wlaker, J.C.G., 1995, Climatic forcing of carbon-oxygen isotopic covariance in temperate-region marl lake: Geology, v. 23, p. 1031-1034.

Dumitru, T.A., Zhou, D., Chang, E.Z., Graham, S.A., Hendrix, M.S., Sobel, E.R., and Caroll, A.R., 2001, Uplift, exhumation, and deformation in the Chinese Tian Shan, in Hendrix, M.S., and Davis, G.A., eds., Paleozoic and Mesozoic tectonic evolution of central Asia : From continental assembly to 
intracontinental deformation: Boulder : colorado, Geological Society of America Memoir 194, p. 71-99.

Fan, M., Dettman, D.L., Song, C., Fang, X., and Garzione, C.N., 2007, Climatic variation in the Linxia basin, NE Tibetan Plateau, from 13.1 to 4.3 Ma: The stable isotope record: Palaeogeography, Palaeoclimatology, Palaeoecology, v. 247, p. 313-328.

Farquhar, G., 1989, Carbon isotope descrimination and photosynthesis: Anual Review of Plant Physiology and Plant Molecular Biology, v. 40, p. 503-537.

Fluteau, F., Ramstein, G., and Besse, J., 1999, Simulating the evolution of the Asian and African monsoons during the past 30 millions years using an atmopsheric general circulation model: Journal of Geophysical Research, v. 104, p. 11995-12018.

Friedman, I., and O'Neil, J.R., 1977, Compilation of stable isotope fractionation factors of geochemical interest. I, in Fleischer, M., ed., Data of geochemistry, U.S. Geol. Surv., p. 440.

Gajurel, A.P., France-Lanord, C., Huyghe, P., Guilmette, C., and Damayanti, G., 2006, C and O isotope compositions of modem fresh-water mollusc shells and river waters from the Himalaya and Ganga plain. : Chemical Geology., v. 233, p. 156-183.

Gao, J., Li, M., Xiao, X., Tang, Y., and He, G., 1998, Paleozoic tectonic evolution of the Tianshan Orogen, northwestern China: Tectonophysics, v. 287, p. 213-231.

Garzione, C.N., Dettman, D.L., and Horton, B.K., 2004, Carbonate oxygen isotope paleoaltimetry: evaluating the effect of diagenesis on paleoelevation estimates for the Tibetan plateau: Palaeogeography, Palaeoclimatology, Palaeoecology, v. 212, p. 119-140.

Garzione, C.N., Dettman, D.L., Quade, J., DeCelles, P.G., and Butler, R.F., 2000, High times on the Tibetan Plateau : Paleoelevation of the Thakkhola graben, Nepal: Geology, v. 28, p. 339-342.

Garzione, C.N., Molnar, P., Libarkin, J.C., and MacFadden, B.J., 2006, Rapid late Miocene rise of the Bolivian Altiplano: Evidence for removal of mantle lithosphere: Earth \& Planetary Science Letters, v. 241, p. 543-556.

Goudie, A.S., 1983, Calcretes, in Goudie, A.S., and Pye, K., eds., Chemical sediments and geomorphology: precipitates and residua in the nearsurface environment: London, Academic Press, p. 93-132.

Graham, A.S., Chamberlain, C.P., Yue, Y., Ritts, B.D., Hanson, A., Horton, T.W., Waldbauer, J.R., Poage, M.A., and Feng, X., 2005, Stable isotope records of Cenozoic climate and topography, Tibetan Plateau and Tarim basin: American Journal of Science, v. 305, p. 101-118.

Hendrix, M.S., Dumitru, T.A., and Graham, A.S., 1994, Late Oligocene-early Miocene unroofing in the Chinese Tian Shan : An early effect of the India-Asia collision: Geology, v. 22, p. 487-490.

Hendrix, M.S., Graham, A.S., Carroll, A.R., Sobel, E.R., McKnight, C.L., Schulein, B.J., and Wang, Z., 1992, Sedimentary record and climatic implications of deformation in the Tian Shan : Evidence from Mesozoic strata of the north Tarim, south Junggar, and Turpan Basins, northwest China: Geological Society of American Bulletin, v. 104, p. 53-79.

Ingraham, N.L., and Taylor, B.E., 1991, Light stable isotope systematics of large-scale hydrologic regimes in California and Nevada: Water Resources Research, v. 127, p. 77-90.

Jolivet, M., Dominguez, S., Charreau, J., Chen, Y., Li, Y., and Wang, Q., 2010, Mesozoic and Cenozoic tectonic history of the central Chinese TianShan: Reactivated tectonic structures and active deformation: Tectonics, v. 29, p. doi:10.1029/2010TC002712.

Kent-Corson, M.L., Ritts, B.D., Zhuang, G., Bovet, P.M., Graham, S.A., and Chamberlain, C.P., 2009, Stable isotopic constraints on the tectonic, topographic, and climatic evolution of the northern margin of the Tibetan Plateau: Earth \& Planetary Science Letters, v. 282 p. 158-166.

Koch, P.L., 1998, Isotopic reconstruction of past continental environments, in Jeanloz, R.A., A.L., and Burke, K.C., eds., Annual review of earth and planetary sciences: Palo Alto, California, p. 573613. 
Koons, P.O., 1987, Some thermal and mechanical consequences of rapid uplift: an example from the Southern Alps, New Zealand: Earth and Planetary Science Letters, v. 86 p. 307-319.

Körner, C., Farquhar, G., and Wong, S.C., 1991, Carbon isotope discrimination by plants follows latitudinal and altitudinal trends: Oecologia, v. 88, p. 30-40.

Leech, M.L., Singh, S., Jain, A.K., Klemperer, S.L., and Manickavasagam, R.M., 2005, The onset of IndiaAsia continental collision: Early, steep subduction required by the timing of UHP metamorphism in the western Himalaya. : Earth and Planetary Science Letters v. 234.

Lourens, L., Hilgen, F., Shackleton, N.J., Laskar, J., and Wilson, D., 2004, The Neogene Period, in Felix M. Gradstein, J.G.O., and Alan G. Smith, ed., A Geological Time Scale: London, Cambridge.

Métivier, F., Gaudemer, Y., Tapponnier, P., and Klein, M., 1999, Mass accumulation rates in Asia during the Cenozoic: Geophysical Journal International, v. 137, p. 280-318.

Molnar, P., 2005, Mio-Pliocene growth of the Tibetan PLateau and evolution of east Asian Climate: Paleontologia Electronica, v. 8, p. 1-23.

Molnar, P., and England, P., 1990, Late Cenozoic uplift of mountain ranges and global climate change: chicken or egg?: Nature, v. 346, p. 29-34.

Passey, B.H., Ayliffe, L.K., Kaakinen, A., Zhang, Z., Eronen, J.T., Zhu, Y., Zhou, L., Cerling, T.E., and Fortelius, M., 2009, Strengthened East Asian summer monsoons during a period of high-latitude warmth? Isotopic evidence from Mio-Pliocene fossil mammals and soil carbonates from northern China: Earth and Planetary Science Letters, v. 277, p. 443-452.

Patriat, P.A., and Achache, J., 1984, India-Eurasia collision chronology has implications for crustal shortening and driving mechanisms of plates: Nature, v. 311, p. 615-621.

Poage, M.A., and Chamberlain, C.P., 2001, Empiritical relationships between elevation and the stable isotope composition of precipitation and surface waters: considerations for studies of paleoelevation change American Journal of Science, v. 901, p. 1-18.

Quade, J., Breecker, D.O., Daëron, M., and Eiler, J., 2011, The paleoaltimetry of Tibet: an isotopic perspective: American Journal of Science, v. 311, p. 77-115.

Quade, J., and Cerling, T.E., 1995, Expansion of C4 grasses in the Late Miocene of nrthern Pakistan: evidence from stable isotopes of paleosols: Palaeogeography, Palaeoclimatology, Palaeoecology, v. 115, p. 91-116.

Quade, J., Cerling, T.E., and Bowman, J.R., 1989, Development of Asian monsoon revealed by marked ecological shift during the latest Miocene in northern Pakistan: Nature, v. 342, p. 163-166.

Quade, J., and Roe, L.J., 1999, The stable-isotope composition of early ground-water cements from sandstone in paleocological reconstruction: Journal of Sedimentary Research, v. 69, p. 667-674.

Raymo, M.E., and Ruddiman, W.F., 1992, Tectonic forcing of Late Cenozoic climate: Nature, v. 359, p. 117-122.

Reigber, C., Michel, G.W., Galas, R., Angermann, D., Klotz, J., Chen, J.Y., Papschev, A., Arslanov, R., and Tzurkov, V.E., Ishanov, M.C., 2001, New space geodetic constraints on the distribution of deformation in the Central Asia: Earth and Planetary Science Letters, v. 191, p. 157-165.

Rowley, D.B., and Currie, B.S., 2006, Paleo-altimetry of late Eocene to Miocene Lunpola basin, central Tibet: Nature, v. 439, p. 677-681.

Rowley, D.B., Pierrehumbert, R.T., and Currie, B.S., 2001, A new approach to stable isotope-based paleoaltimetry: implications ofr paleoaltimetry and paleohypsometry of the High Himalaya since the Late Miocene: Earth \& Planetary Science Letters, v. 188, p. 253-268.

Ruddiman, W.F., and Kutzbach, J.E., 1989, Forcing of late Cenozoic northern hemisphere climate by plateau uplift in southern Asia and the American West: Journal of Geophysical Research, v. 94, p. 18409-18427.

Sammel, E.A., and Craig, R.W., 1981 The geothermal hydrology of Warner Valley, Oregon: a reconnaissange study.: U.S. Geol. Surv. Prof. , p. Paper 1044-I. 
Sanyal, P., Bhattachary, S.K., and Prasad, M., 2005, Chemical diagenesis of Siwalik sandstone: Isotopic and mineralogical proxies from Surai Khola section, Nepal: Sedimentary Geology, v. 180, p. 5774.

Siegenthaler, U., and Oeschger, H., 1980 , Correlation of ${ }^{18} \mathrm{O}$ in precipitation with temperature and altitude: Nature, v. 285, p. 189-223.

Sobel, E.R., and Dumitru, T.A., 1997, Thrusting and exhumation around the margins of the western Tarim basin during India-Asia collision: Journal of Geophysical Research, v. 102, p. 5043-5063.

Suarez, M.B., Passey, B.H., and Kaakinen, A., 2011, Paleosl carbonate multiple isotopologue signature of active East Asian summer monsoons during the late Miocene and Pliocene: Geology, v. In press.

Sun, J., Xu, Q., and Huang, B., 2007, Late Cenozoic magnetochronology and paleoenvironmental changes in the northern foreland basin of the Tian Shan Mountains: Journal of Geophysical Research B: Solid Earth, v. 112, p. doi:10.1029/2006JB004653.

Sun, J., and Zhang, Z., 2008, Palynological evidence for the Mid-Miocene Climatic Optimum recorded in Cenozoic sediments of the Tian Shan Range, northwestern China: Global and Planetary Change, v. 64, p. 53-68.

Talbot, M.R., 1990, A review of the palaeohydrological interpretation of carbon and oxygen isotopic ratios in primary lacustrine carbonates: Chemical Geology, v. 80, p. 261-279.

Tapponnier, P., and Molnar, P., 1979, Active faulting and cenozoic tectonics of the Tien Shan, Mongolia, and Baykal regions: Journal of Geophysical Research, v. 84, p. 3425-3459.

Tieszen, L., 1991, Natural variations in the carbon isotope value of plants: implications for archaeology, ecology and paleoecology: Journal of Archaeology Science, v. 18, p. 227-248.

Wang, B., Faure, M., Shu, L., Cluzel, D., Charvet, J., De Jong, K., and Chen, Y., 2008a, Paleozoic tectonic evolution of the Yili Block, western Chinese Tianshan: Bullentin de la Société Géologique de France, v. 179 p. 483-490.

Wang, Y., and Deng, T., 2005, A 25 m.y. isotopic record of paleodiet and environmental change from fossil mammals and paleosols from the NE margin of the Tibetan Plateau: Earth and Planetary Science Letters, v. 236, p. 322-338.

Wang, Y., Kromhout, E., Zhang, C., Xu, Y., Parker, W., Deng, T., and Qiu, Z., 2008b, Stable Isotopic variations in modern herbivore tooth enamel, plants and water on the Tibetan Plateau: Implications ofr paleoclimate and paleoelevation reconstructions: Palaeogeography Palaeoclimatology Palaeoecology, v. 260, p. 359-374.

Whipple, K.X., and Meade, B.J., 2006, Orogen response to changes in climatic and tectonic forcing: Earth and Planetary Science Letters, v. 243, p. 218-228.

Windley, B.F., Allen, M.B., Zhang, C., Zhao, Z.-Y., and Wang, G.R., 1990, Paleozoic accretion and Cenozoic deformation of the Chinese Tien Shan Range, central Asia: Geology, v. 18, p. 128-131.

Zhang, C., Wang, Y., Deng, T., Wang, X., Biasatti, D., Xu , Y., and Li, Q., 2009, C4 expansion in the central Inner Mongolia during the latest Miocene and early Pliocene: Earth and Planetary Science Letters, v. 287 p. 311-319.

Zhang, P., Molnar, P., and Downs, W.R., 2001, Increased sedimentation rates and grain sizes 2-4 Myr ago due to the influence of climate change on erosion rates: Nature, v. 410, p. 891-897.

Zhuang, G., Hourigan, J.K., Ritts, B.D., and Kent-Corson, M.L., 2011, Cenozoic multiple-phase tectonic evolution of the northern Tibetan Plateau: Constraints from sedimentary records from Qaidam basin, Hexi Corridor, and Subei basin, northwest China (2011): American Journal of Science, v. 311. 

Figure caption 


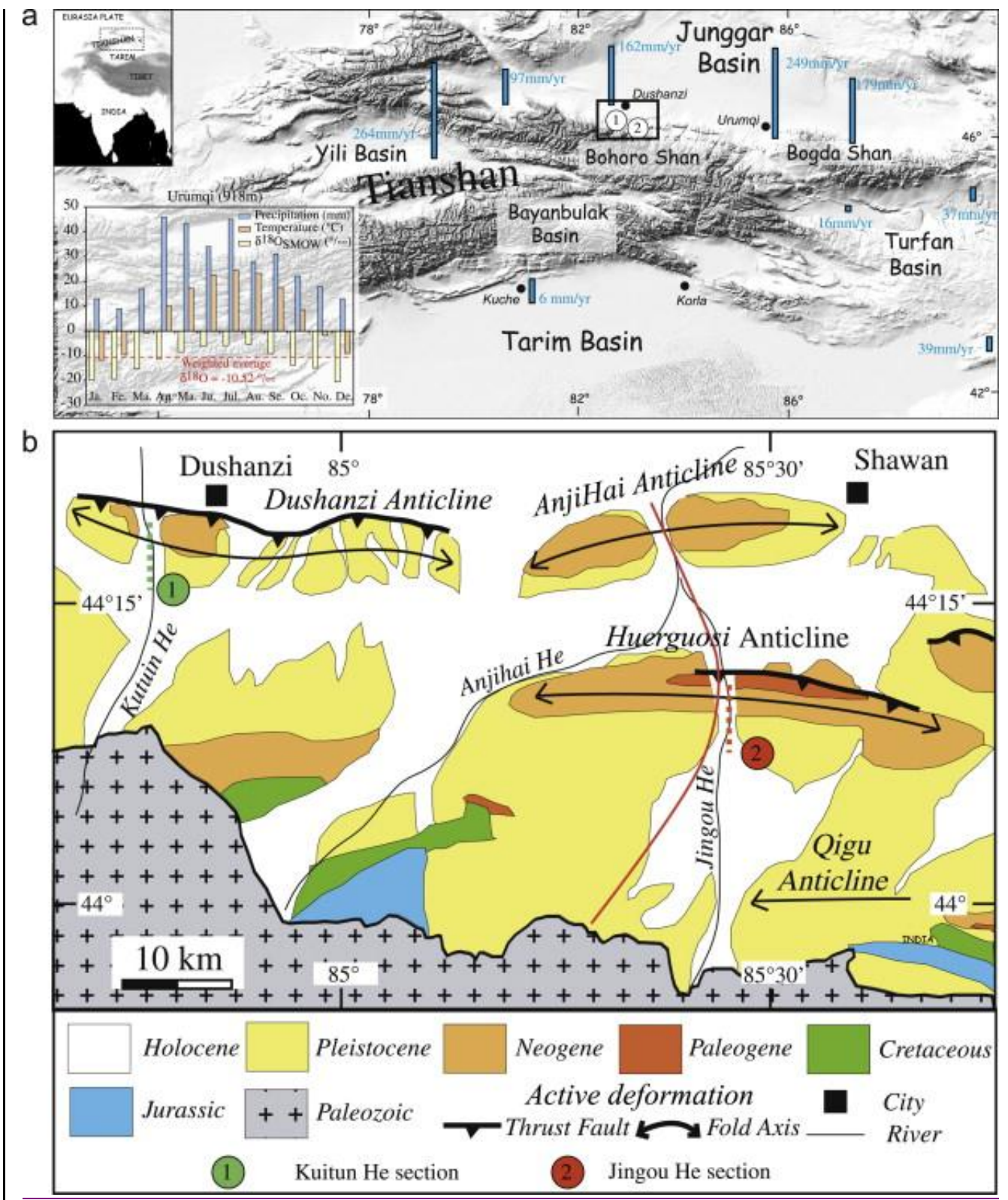

Figure 1: (a) topographic map of central Asia (Insert shows precipitation, temperature and isotopic composition of rainfall at Urumqi according to the Global Network of Isotope Precipitation database); (b) geological map of the Dushanzi area with the location of the Jingou He and Kuitun He sections (modified after BGMRX, 1985). 


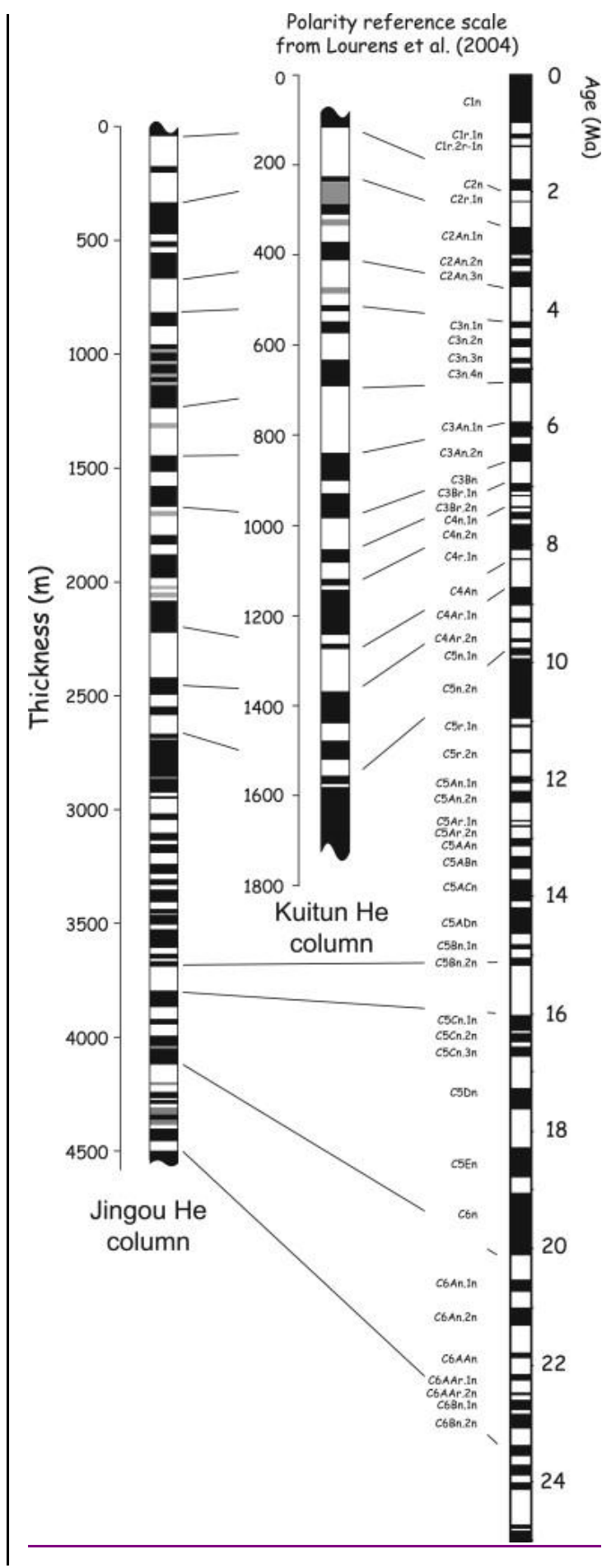


Figure 2: magnetostratigraphic columns of the Kuitun He (Charreau et al., 2011; Charreau et al., 2005) and the Jingou He (Charreau et al., 2009a) sections and their correlations to the magnetic reference scale (Lourens et al., 2004). 


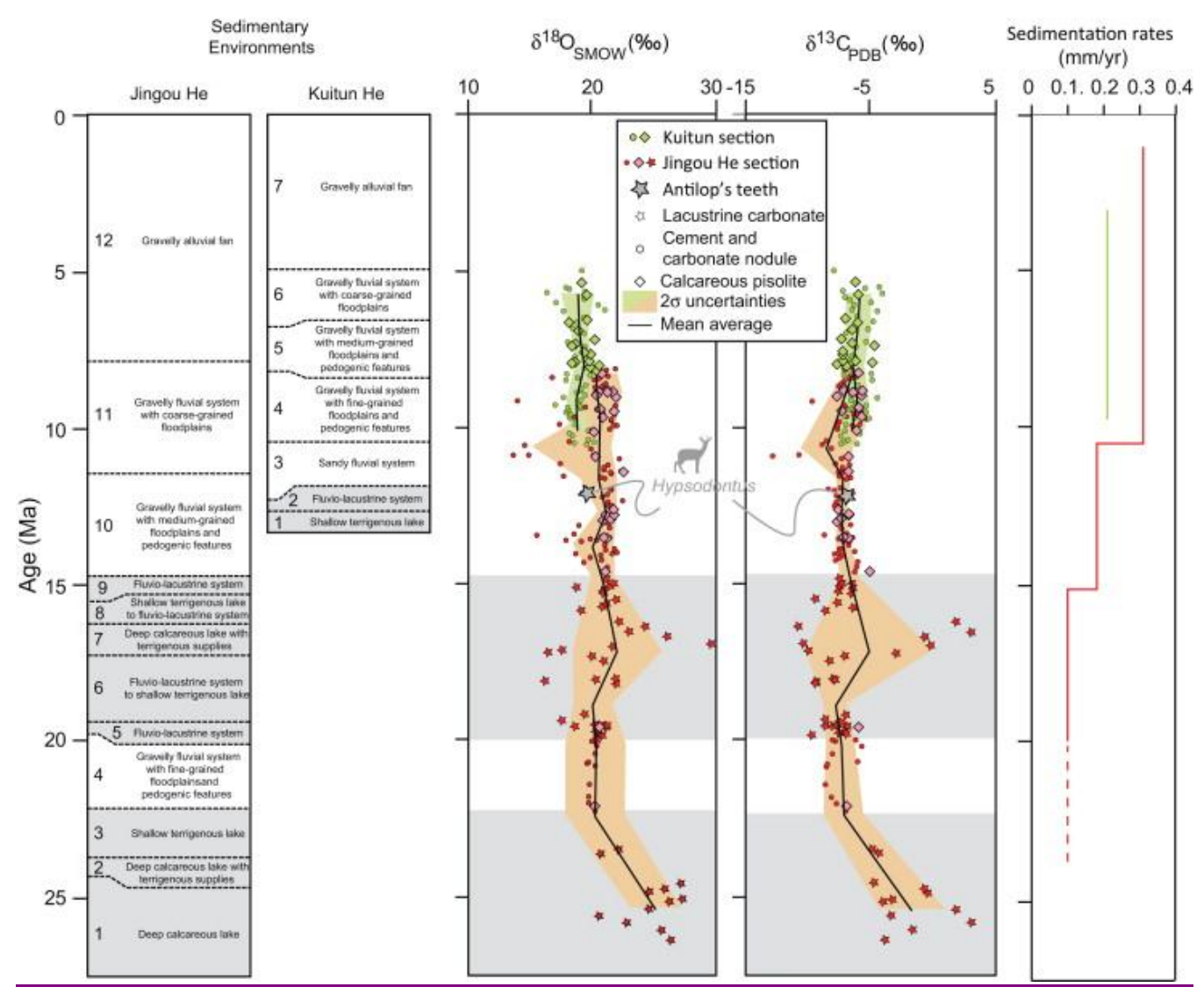

Figure 3: (a) sedimentary environment evolution; (b) plot of $\delta^{18} \mathrm{O}_{\mathrm{SMOW}}$ and $\delta^{13} \mathrm{C}_{\mathrm{PDB}}$ values of the different type of carbonate against time for both sections, heavy solid line shows the averages of a sliding window shifted every $\sim 200 \mathrm{~m} ; 1 \sigma$ uncertainties in color; (c) evolution of the accumulation rates in the the Jingou $\mathrm{He}$ (red line) and Kuitun $\mathrm{He}$ (green line) sections derived from our magnetostratigraphic analysis. In both sections the identification of pedogenic nodules fluviatil sediments remained often tenuous in the field. Therefore only calcareous pisolite have a reliable pedogenic origin and have been distinguished. 


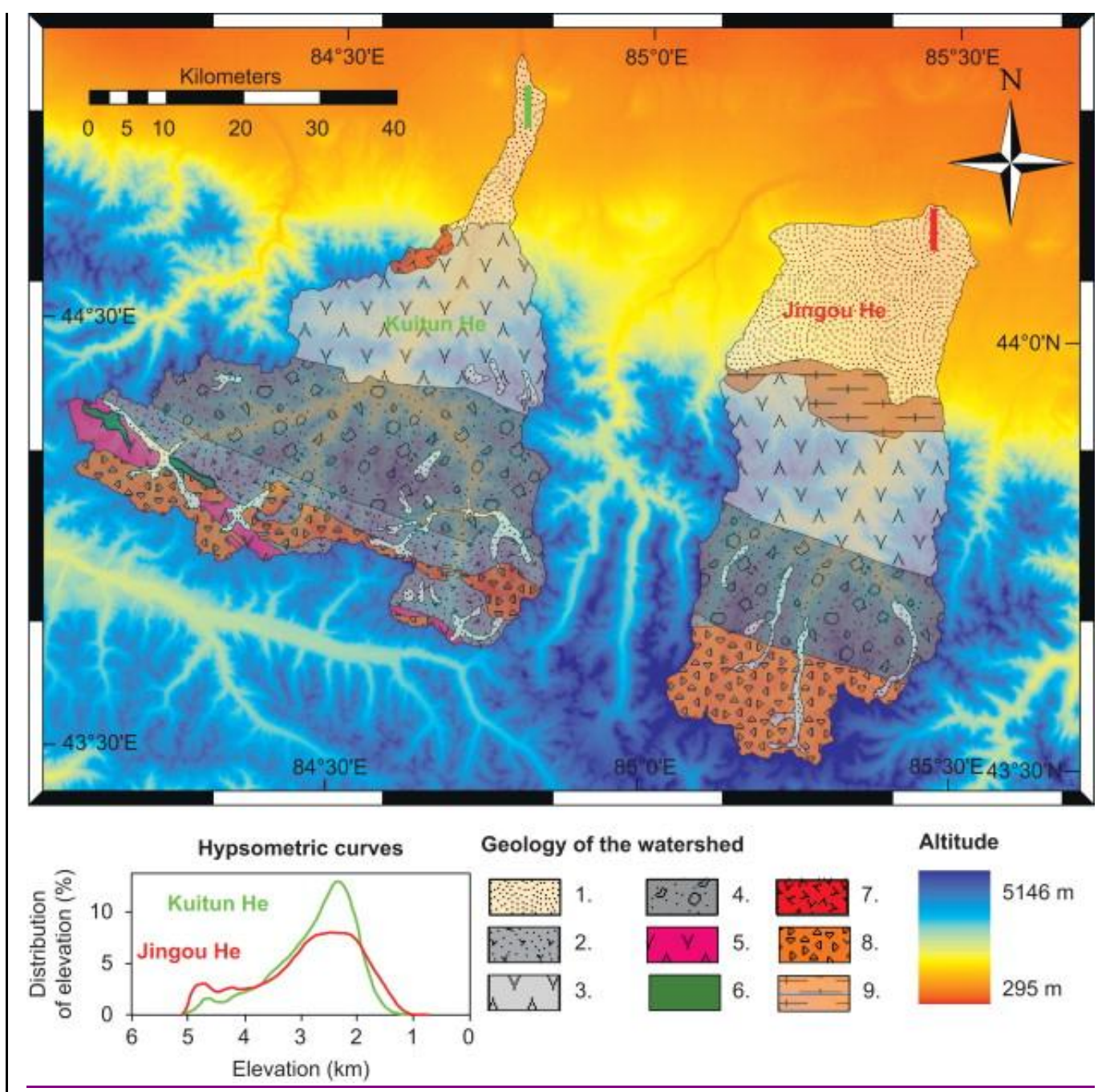

Figure 4: topographic map of the Dushanzi area showing the drainage basins of both the Kuitun and Jingou rivers and their geology including: 1. Mesozoic to Cenozoic fluviolacustrine foreland deposits, 2. Carboniferous volcanic breccia interbedded with limestone, 3. Carboniferous tuff, andesite, basalt and volcanic breccia, 4. Devonian tuff and breccia, 5 and 6. Silurian sandstone, 7 and 8. granite. 9. Permian sandstone and conglomerate. At the bottom left, the plot shows the distribution in elevation for both basins for the Kuitun He (green line) and the Jingou He (red line) derived from the SRTM digital elevation model. 


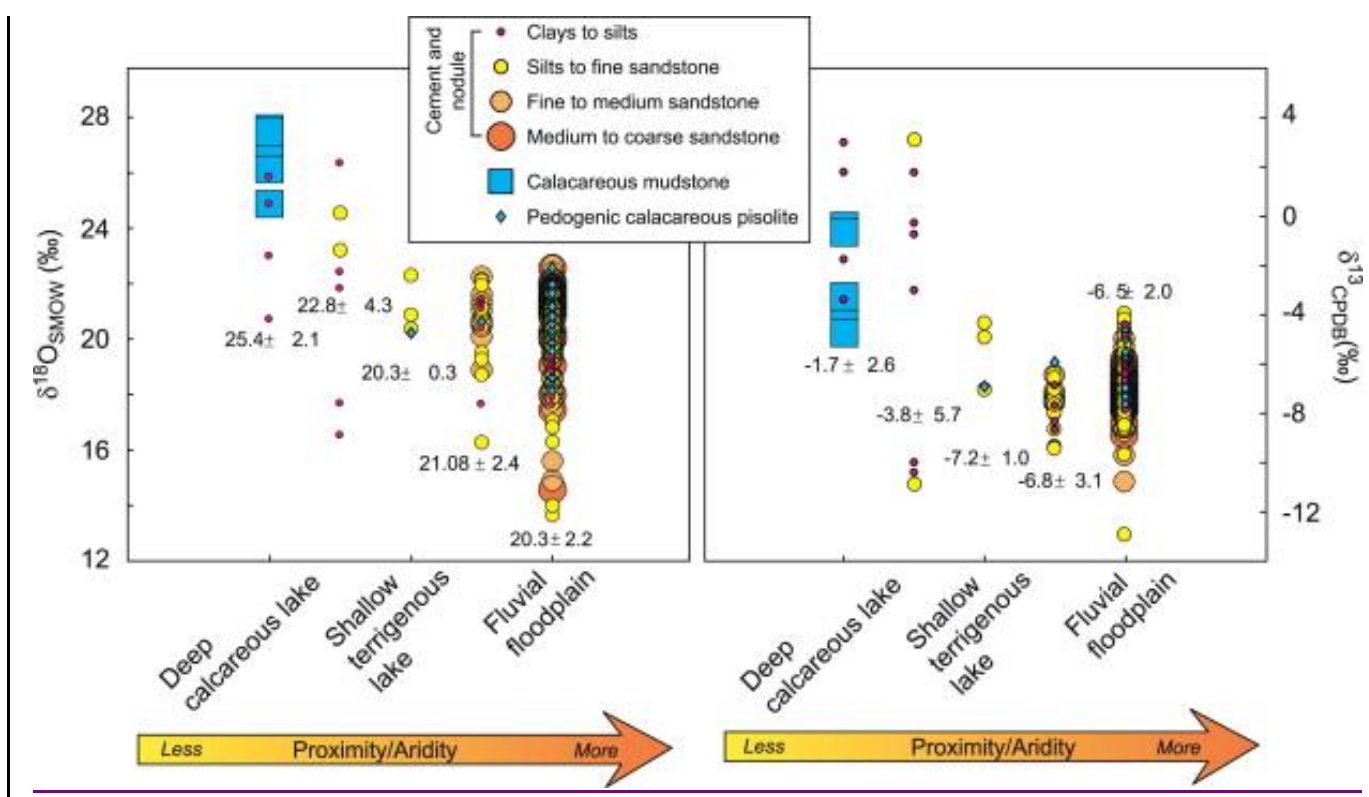

Figure 5: $\delta^{18} \mathrm{O}_{\mathrm{SMOW}}$ and a $\delta^{13} \mathrm{C}_{\mathrm{PDB}}$ values and lithology (grain size) plotted against interpreted depositional environments and their interpreted aridity. Circles correspond to carbonate cement while their size and color show the samples lithology. Blue scare are carbonate mudstone sampled in lacustrine deposits while the blue diamond represent the pedogenic carbonate samples. Below each column is given the average isotopic values (in \%o) measured in each of the interpreted depositional environment. 


\begin{tabular}{ccccccc} 
Section & \multicolumn{7}{c}{$\delta^{18} \mathrm{O}_{\text {Meteoric Water }}$ (SMOW; \%) } \\
& 5 & 10 & 15 & 20 & 25 & 30 \\
& $\left({ }^{\circ} \mathrm{C}\right)$ & $\left({ }^{\circ} \mathrm{C}\right)$ & $\left({ }^{\circ} \mathrm{C}\right)$ & $\left({ }^{\circ} \mathrm{C}\right)$ & $\left({ }^{\circ} \mathrm{C}\right)$ & $\left({ }^{\circ} \mathrm{C}\right)$
\end{tabular}

Kuitun He $67-14.2 \pm 0.8-12.7 \pm 0.8-11.5 \pm 0.8-10.4 \pm 0.8-9.3 \pm 0.8-8.3 \pm 0.8$

Jingou He $117^{\mathrm{a}}-12.8 \pm 2.4-11.6 \pm 2.4-10.4 \pm 2.4-9.3 \pm 2.4 \quad-8.2 \pm 2.4-7.2 \pm 2.4$

a

Only samples from fluvial system. 
Table 1: average $\delta^{18} \mathrm{O}_{\text {Meteoric Water }}(\mathrm{SMOW} ; \%$ ) values for both section calculated based on the average $\delta^{18} \mathrm{O}_{\text {carbonate }}(\mathrm{SMOW})$ values and supposed crystallization temperature ranging from $5^{\circ} \mathrm{C}$ to $30^{\circ} \mathrm{C}$. $\mathbf{n}$ is the number of sample used to average the $\delta^{18} \mathrm{O}_{\text {carbonate }}(\mathrm{SMOW})$ which exclude lacustrine samples for the Jingou He section. 
Table1

\begin{tabular}{lccccccc}
\hline \multirow{2}{*}{ Section } & $\mathrm{n}$ & \multicolumn{5}{c}{$\delta^{18} \mathrm{O}_{\text {Meteoric Water }(\mathrm{SMOW} \% \text { \%o }}$} \\
\cline { 3 - 8 } & & $5^{\circ} \mathrm{C}$ & $10^{\circ} \mathrm{C}$ & $15^{\circ} \mathrm{C}$ & $20^{\circ} \mathrm{C}$ & $25^{\circ} \mathrm{C}$ & $30^{\circ} \mathrm{C}$ \\
\hline Kuitun He & 67 & $-14.2 \pm 0.8$ & $-12.7 \pm 0.8$ & $-11.5 \pm 0.8$ & $-10.4 \pm 0.8$ & $-9.3 \pm 0.8$ & $-8.3 \pm 0.8$ \\
Jingou He & $117^{*}$ & $-12.8 \pm 2.4$ & $-11.6 \pm 2.4$ & $-10.4 \pm 2.4$ & $-9.3 \pm 2.4$ & $-8.2 \pm 2.4$ & $-7.2 \pm 2.4$ \\
\hline
\end{tabular}

* only samples from fluvial system 